DOI: https://doi.org/10.24144/2409-6857.2018.1(51).257-261

УДК 338.2

Постол А.А.

\title{
УДОСКОНАЛЕННЯ СКЛАДОВИХ ТА МЕХАНІЗМІВ ІНСТИТУЦІЙНОГО ЗАБЕЗПЕЧЕННЯ КОНКУРЕНТОСПРОМОЖНОГО РОЗВИТКУ АГРАРНИХ ПІДПРИЕМСТВ
}

\begin{abstract}
В роботі розглянуто науково-методичні підходи до формування інституиійних складових та механізмів забезпечення ефективного й конкурентоспроможного розвитку аграрних підприємств. Виявлено, що інституиійне забезпечення представлене сукупністю державних та громадських або суспільних інститутів. Визначено їх представництво, напрями впливу та функиії. Виявлено вузькі місия й резерви та джерела удосконалення. Особливо ие стосується формування суспільних інститутів та їх діï.
\end{abstract}

Ключові слова: аграрні підприємства, конкурентоспроможний розвиток, складові, механізми, інституиійне забезпечення, удосконалення.

Постановка проблеми. Розвиток аграрних підприємств в умовах ринку як системи інституцій, які впливають на внутрішню структуру організації діяльності підприємств у процесі обміну ресурсами та результатами їх переробки, неможливий без належного інституційного забезпечення. Для того щоб побудувати цілісну концепцію розвитку аграрних підприємств, враховуючи досвід попередніх трансформацій, потрібно дослідити інституційні умови функціонування підприємств сьогодні, тобто рівень достатності інституційної забезпеченості процесу розвитку аграрної сфери.

Аналіз останніх досліджень і публікацій. У сфері інституційних досліджень наявні плідні здобутки зарубіжних та вітчизняних дослідників: Т. Веблена, К. Менара, В. Андрійчука, О. Бородіної, П. Гайдуцького, О. Гончаренка, М. Ігнатенка, Ю. Лопатинського, М. Маліка, Л. Мармуль, П. Саблука, О. Шпикуляка та інших. Проте ступінь дослідження інституційного забезпечення залишається недостатнім у контексті необхідності його удосконалення 3 метою конкурентоспроможного розвитку аграрних підприємств шляхом спільного впливу державних та суспільних, формальних та неформальних інститутів та інституцій.

Погоджуючись iз думкою Гончаренко О., вважаємо, що інституційна та інноваційна компонента конкурентоспроможного розвитку аграрних підприємств $є$ ключовими та безпосередньо мають вплив одна на одну. На вагомій суспільній значущості формування дієвого інституційного механізму розвитку аграрних підприємств на базі соціально-економічної та

(c) Постол Анатолій Анатолійович, кандидат політичних наук, доцент, докторант, ДВНЗ “Херсонський державний аграрний університет", м. Херсон, email: postagrostor@gmail.com культурної спадщини минулих трансформацій та передового зарубіжного досвіду наголошують Лопатинський Ю. та Кифяк В.

Формулювання цілей статті. Метою статті $\epsilon$ обгрунтування удосконалення інституційного забезпечення ефективного й конкурентоспроможного розвитку аграрних підприємств на основі удосконалення не лише державних, але й громадських або суспільних інститутів та їх узгодженої взаємодії.

Опис основного матеріалу дослідження. Інституційне забезпечення розвитку аграрних підприємств визначено як владні інститути, ЗМI, навчальні заклади, сільські громади, сільські родини та їх діяльність і процеси взаємодії i впливу на безперервне формування середовища, яке найбільшою мірою сприяло б самоорганізації аграрних суб'єктів господарювання. Вони являють собою складні комплекси функціонуючих елементів [1, с. 132]. Тобто це динамічний вплив, на розвиток аграрних господарств організацій, інституцій у певному синергетичному взаємозв'язку.

Формування системи інституційного забезпечення розвитку аграрних підприємств передбачає упорядковану сукупність формальних і неформальних інституцій, що визначають та регулюють його територіальні, соціальні, виробничо-економічні, екологічні, нормативноправові й організаційно-управлінські параметри. Складові інституційного середовища визначають пріоритети в рамках триєдиної системи соціальноекономічних, законодавчих або політичних інституцій формального змісту та неформальних ідеологічних інституцій.

Система інституціонального регулювання аграрних підприємств включає такі суб'єкти: органи управління підприємством, інноваційну службу, інфраструктуру підприємства. Основними 
об'єктами інституціонального регулювання є безпосередньо виробництво, інноваційні відносини, кадри, ресурси, неформальні обмеження. Вихідними умовами запровадження регулюючих впливів виступають визначені цілі та ресурси інноваційного розвитку. Метою інституціональних регулюючих заходів $є$ реалізація інноваційних проектів, інноваційний розвиток підприємства та зростання його конкурентоспроможності [2, с. 5].

Управління розвитком аграрних підприємств в Україні представлено двома механізмами: державним та громадським. Вважаємо, що саме дисбаланс у їхніх повноваженнях i породжує низьку, а то й від'ємну якість інституцій. Недостатні повноваження механізму громадського управління $\epsilon$ також наслідком його неформального підпорядкування першому [3, с. 8]. На нашу думку, саме організована взаємодія та протидія самодостатніх елементів громадського та державного управління повинна формувати ефективне інституційно-управлінське забезпечення розвитку аграрних підприємств.

Громадський механізм контролю в аграрному секторі України представлений через різноманітні об'єднання. Об'єднання аграріїв є формою залучення суб'єктів господарювання до процесу управління аграрним сектором. Адже конкурентоспроможний сектор вимагає у сучасних умовах формування потужного класу підприємців-аграріїв, який має стати основою успішного розвитку. Рівень розвитку громадських організацій аграрного сектора $\epsilon$ індикатором становлення ліберальних відносин у ньому.
Результати опитування показали, що 73\% підприємств не беруть участі в об'єднаннях [4, с. 198]. Лише кожне четверте підприємство є членом ділових або професійних об'єднань (серед середніх підприємств - кожне третє, серед великих - кожне друге підприємство). При цьому керівники підприємств, які не є членами об'єднань, вважають, що не отримають від членства вигоди і не бажають витрачати на це час та гроші. Однією з найважливіших проблем становлення аграрних відносин як ринкових $\epsilon$ так i несформоване інституційне забезпечення прав власності на основний ресурс здійснення аграрної діяльності. Специфікацію інституційного забезпечення аграрних підприємств характеризують ментально-психологічні фактори, які пронизують всі складові інституційного забезпечення [5, с. 21], а саме:

1) брак суспільної відповідальності суб'єктів аграрних відносин;

2) регіональна поляризація суспільних настроїв;

3) низький рівень політичної та громадської активності аграріїв;

4) недовіра населення до системи забезпечення якості продукції;

5) не забезпечується повноцінна участь аграріїв в управлінні аграрними відносинами;

6) низький рівень розвитку руху підприємціваграріїв;

7) високий рівень індивідуалізації суб'єктів підприємницької діяльності в аграрному секторі;

8) відсутність інноваційного та конкурентного духу у підприємців-аграріїв.

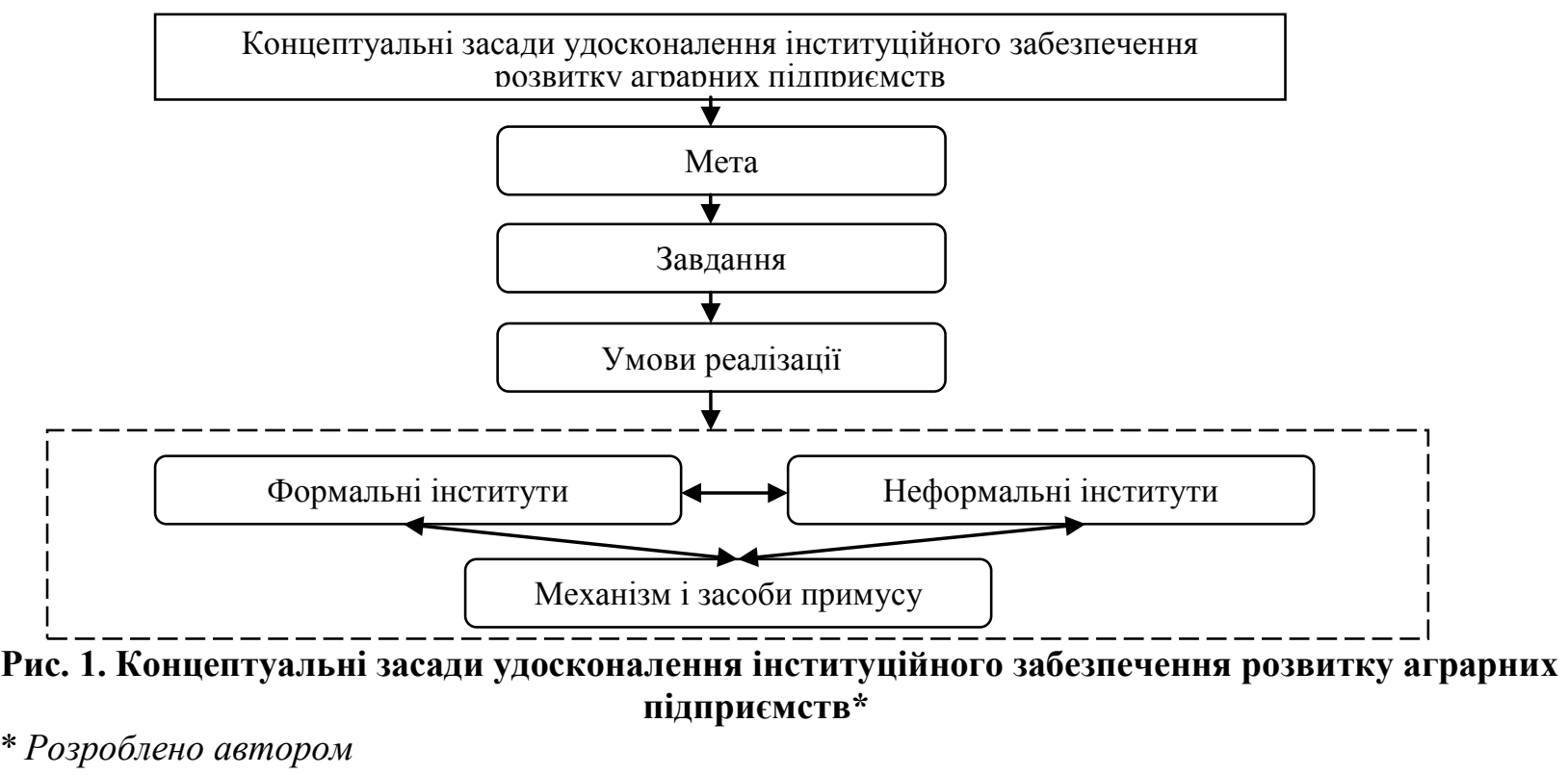

Метою удосконалення інституційного забезпечення розвитку аграрних підприємств повинно стати створення умов для становлення в
Україні моделі сталого, багатофункціонального сільського господарства, яке разом 3 виробництвом якісного i безпечного продовольства, 
сировини й енергії задовольняє інші потреби населення та надає суспільні послуги, спрямовані на формування якісного життєвого середовища та створення умов для зайнятості у сільській місцевості, зміцнення місцевих громад, збереження довкілля, традиційних сільських ландшафтів і біорізноманіття [6, с. 278].

Схематично концептуальні засади удосконалення інституційного забезпечення розвитку аграрних підприємств, представлені на рис. 1.

Пріоритетні завдання удосконалення інституційного забезпечення розвитку аграрних підприємств можуть бути визначені як такі, що створюють умови для реалізації найважливіших функцій підприємництва: новаторської, організаційної, господарської, соціальної, особистісної (табл. 1).

Таблиця 1

Пріоритетні завдання удосконалення інституційного забезпечення розвитку аграрних підприємств [7]

\begin{tabular}{|c|c|}
\hline $\begin{array}{c}\text { Реалізація функцій } \\
\text { підприємництва }\end{array}$ & Зміст \\
\hline \multirow{6}{*}{$\begin{array}{c}\text { Господарсько- } \\
\text { організаційна }\end{array}$} & $\begin{array}{l}\text { Збільшення кількості суб’єктів підприємницької діяльності, підвищення рівня ділової } \\
\text { активності }\end{array}$ \\
\hline & Поліпшення ресурсного та матеріально-технічного забезпечення суб’єктів підприємництва \\
\hline & $\begin{array}{l}\text { Підвищення рівня ефективності фінансово-господарської діяльності } \\
\text { мотивації населення сільських територій до підприємницької діяльності }\end{array}$ \\
\hline & $\begin{array}{l}\text { Активізація інтеграційних та кооперативних процесів } \\
\text { підприємництва аграрної сфери та іншими секторами економіки }\end{array}$ \\
\hline & Зниження трансакційних витрат суб’єктів підприємницької діяльності \\
\hline & Забезпечення протидії рейдерству та протиправному захопленню майна, активів \\
\hline \multirow{3}{*}{ Новаторська } & Збільшення частки інноваційної продукції, випущеної підприємствами \\
\hline & Розбудова інформаційно-консультативної інфраструктури \\
\hline & Побудова служби дорадництва \\
\hline Соціальна & $\begin{array}{l}\text { Зростання показників: кількість шкіл, дитячих садочків, лікарень, доріг, культурних } \\
\text { закладів, доріг з твердим покриттям, доступ до мережі Internet, сучасного зв'язку }\end{array}$ \\
\hline \multirow{3}{*}{ Особистісна } & Збільшення доходів від підприємницької діяльності мешканців сільських територій \\
\hline & Підвищення привабливості способу життя на сільських територіях \\
\hline & Можливість самореалізації і всебічного розвитку \\
\hline
\end{tabular}

Розробка заходів, орієнтованих на досягнення означених завдань, повинна будуватись на певних принципах 3 дотриманням однозначних засад розвитку бізнес-середовища [7, с. 135]. Серед них чільне місце займають засоби та принципи соціальної відповідальності. Зокрема, йдеться про добровільність; інтегрованість у бізнес-процеси та бізнес-стратегії; системність; користь для всіх заінтересованих сторін: співробітників, споживачів, акціонерів, громади тощо, а також для самого підприємства; забезпечення внесків у вирішення екологічних, соціальних та інших проблем сталого розвитку $[8$, c. 165$]$.

Таблиця 2

Основні принципи удосконалення інституційного забезпечення розвитку аграрних підприємств [9]

\begin{tabular}{|c|c|}
\hline Принципи & Зміст \\
\hline $\begin{array}{l}\text { Опосередкованість впливу } \\
\text { регуляторного рішення }\end{array}$ & $\begin{array}{l}\text { Відмова від прямого впливу } \\
\text { підприємств чи груп підприємств }\end{array}$ \\
\hline $\begin{array}{l}\text { Урахування ефекту масштабу дії } \\
\text { регуляторного рішення }\end{array}$ & $\begin{array}{l}\text { Врахування економічної } \text { віддачі } \text { не від конкретного } \\
\text { підприємства, а від масиву споріднених підприємств }\end{array}$ \\
\hline $\begin{array}{l}\text { Безособовість функціонування } \\
\text { органів державної влади }\end{array}$ & $\begin{array}{l}\text { Усунення будь-якої суб’єктивної вибірковості щодо реагування органами } \\
\text { державної влади на ринкову ситуацію чи діяльність окремого суб'єкта } \\
\text { підприємницької діяльності }\end{array}$ \\
\hline $\begin{array}{l}\text { Саморегульованість у ринковому } \\
\text { середовищі }\end{array}$ & $\begin{array}{l}\text { Будь-який механізм регулювання не повинен вимагати додаткових } \\
\text { регуляторних актів прямого впливу }\end{array}$ \\
\hline Прозорість і відкритість процедур & $\begin{array}{l}\text { Запропоновані дії мають бути вичерпно деталізовані i публічно } \\
\text { встановлені регулятором }\end{array}$ \\
\hline $\begin{array}{l}\text { Конкурентність заходів } \\
\text { стимулювання }\end{array}$ & Попередження нецінової конкуренції та захист прав споживача \\
\hline
\end{tabular}


Головними принципами повинні бути прозорість і відкритість процедур, відмова від підтримки діяльності конкретних підприємств чи груп підприємств, усунення будь-якої суб'єктивності щодо реагування влади на діяльність окремого суб'єкта підприємницької діяльності, підтримка саморегульованості і конкурентності у ринковому середовищі (табл. 2) $[9$, с. 44]. Основні напрями реалізації завдань удосконалення інституційного забезпечення розвитку аграрних підприємств представлені в узагальненому вигляді на рис. 2.

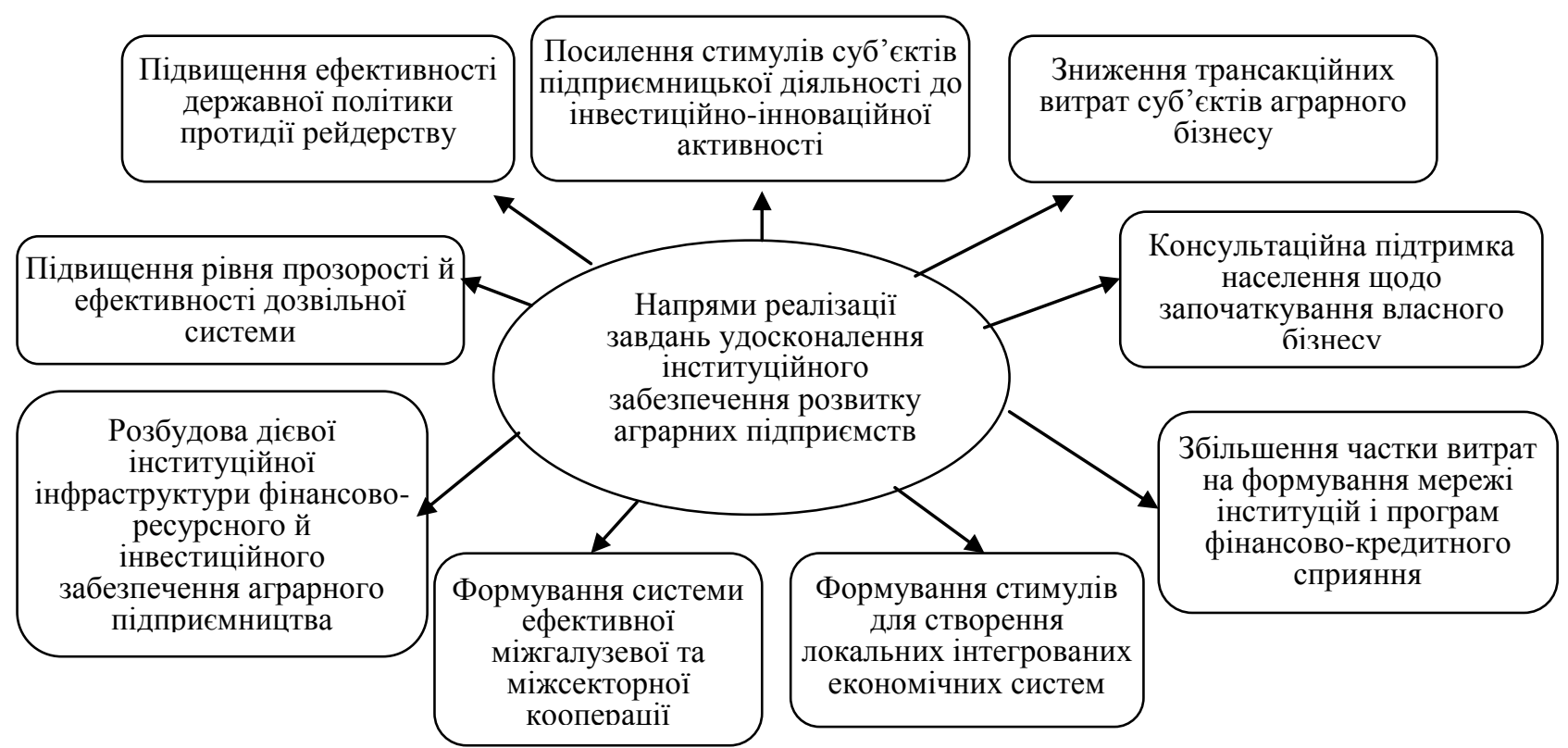

\section{Рис. 2. Напрями реалізації завдань удосконалення інституційного забезпечення розвитку}

* Розроблено автором аграрних підприємств*

Висновки i перспективи подальших досліджень. Удосконалення інституційного забезпечення розвитку аграрних підприємств через посилення його складових дозволить досягти позитивного економічного ефекту, що виражений $\mathrm{y}$ : створенні організаційноекономічних умов для ефективного соціально спрямованого розвитку аграрних підприємств, забезпеченні конкурентоспроможного розвитку, ефективному використанні природних ресурсів, формуванні людського капіталу, стимулюванні розвитку малих i середніх агровиробників, розвитку сільських територій, просвітництві виробників сільськогосподарської продукції, забезпеченні доступності інвестиційних ресурсів, удосконаленні форм і методів державної підтримки, ii прозорості, прогнозованості та системності. Подальші дослідження планується здійснювати у напрямах удосконалення інституційного забезпечення ефективного й конкурентоспроможного розвитку аграрних підприємств.

\section{ПЕРЕЛІК ВИКОРИСТАНИХ ДЖЕРЕЛ}

1. Лопатинський Ю.М. Розвиток аграрного сектора національної економіки на інституційних засадах: [монографія] / Ю.М. Лопатинський, В.І. Кифяк. - Чернівці: Чернівецький нац. ун-т, 2014. - 248 с.

2. Заскалкіна О.М. Концептуалізація розвитку інституціонального середовища в аграрному секторі економіки України / О.М. Заскалкіна // Державне регулювання процесів економічного і соціального розвитку. 2016. - № 4. - С. 1-8.

3. Кіндзерський Ю. Інституціональні аспекти відтворення у контексті структурних трансформацій / Ю. Кіндзерський // Економіка України. - 2007. - № 2. - С. 4-12.

4. Мармуль Л.О. Формування та розвиток інституціональної системи аграрної економіки / Л.О. Мармуль // Інституціональні засади трансформацій в аграрній сфері: зб. наук. пр. - К.: ННУ «IAE» НАAНУ, 2011. - С. $194-$ 203.

5. Єфименко Т. Інституційне регулювання економічного розвитку / Т. Єфименко // Економіка України. 2011. - № 1. - С. 16-26.

6. Шпикуляк О. Г. Інституції аграрного ринку / О. Г. Шпикуляк - К. : ННЦ «IAЕ» УАAН, 2009. - 470 с.

7. Малік М.Й. Інституціоналізація аграрного підприємництва: трансформація та ефективність / М.Й. Малік, О.Г. Шпикуляк // Економіка АПК. - 2010. - № 7. - С. 132-139.

8. Ігнатенко М.М. Інституційні та організаційно-економічні засоби стимулювання соціальної 
відповідальності бізнесу на рівні агропромислових підприємств / М.М. Ігнатенко // Наукові праці Полтавської державної аграрної академії. - Вип. 2 (9). - Полтава: ПДАА, 2014. - С. 163-168.

9. Усюк Т.В. Інституційні аспекти розвитку сільського підприємництва: теоретико-методологічний підхід / Т.В. Усюк // Вісник Житомирського національного агроекологічного університету: науково-теоретичний збірник. - 2011. - № 1 (28) т. 2. - С. 41-48.

\section{REFERENCES}

1. Lopatyns'kyy, Yu.M. \& Kyfyak, V.I. (2014), Rozvytok ahrarnoho sektora natsional'noyi ekonomiky na instytutsiynykh zasadakh [Development of the agrarian sector of the national economy on an institutional basis]. Chernivtsi: Chernivets'kyy nats. un-t (in Ukr.).

2. Zaskalkina, O.M. (2016), Kontseptualizatsiya rozvytku instytutsional'noho seredovyshcha v ahrarnomu sektori ekonomiky Ukrayiny [Conceptualization of the development of the institutional environment in the agrarian sector of the economy of Ukraine]. Derzhavne rehulyuvannya protsesiv ekonomichnoho i sotsial'noho rozvytku, 4, 1-8 (in Ukr.).

3. Kindzers'kyy, Yu. (2007), Instytutsional'ni aspekty vidtvorennya u konteksti strukturnykh transformatsiy [Institutional aspects of reproduction in the context of structural transformations]. Ekonomika Ukrayiny, 2, 4-12 (in Ukr.).

4. Marmul', L.O. (2011), Formuvannya ta rozvytok instytutsional'noyi systemy ahrarnoyi ekonomiky [Formation and development of the institutional system of the agrarian economy], Instytutsional'ni zasady transformatsiy $v$ ahrarniy sferi, 194-203 (in Ukr.).

5. Yefymenko, T. (2011), Instytutsiyne rehulyuvannya ekonomichnoho rozvytku [Institutional regulation of economic development]. Ekonomika Ukrayiny, 1, 16-26 (in Ukr.).

6. Shpykulyak, O.H. (2009), Instytutsiyi ahrarnoho rynku [Agricultural Market Institutions]. Kyyiv: NNTS «IAE» UAAN (in Ukr.).

7. Malik, M.Y. \& Shpykulyak, O.H. (2010), Instytutsionalizatsiya ahrarnoho pidpryyemnytstva: transformatsiya ta efektyvnist' [Institutionalization of agrarian entrepreneurship: transformation and efficiency]. Ekonomika APK, 7, 132-139 (in Ukr.).

8. Ihnatenko, M.M. (2014), Instytutsiyni ta orhanizatsiyno-ekonomichni zasoby stymulyuvannya sotsial'noyi vidpovidal'nosti biznesu na rivni ahropromyslovykh pidpryyemstv [Institutional and organizational and economic means of stimulating social responsibility of business at the level of agro-industrial enterprises]. Naukovi pratsi Poltavs'koyi derzhavnoyi ahrarnoyi akademiyi, 2 (9), 163-168 (in Ukr.).

9. Usyuk, T.V. (2011), Instytutsiyni aspekty rozvytku sil's'koho pidpryyemnytstva: teoretyko-metodolohichnyy pidkhid [Institutional aspects of rural entrepreneurship development: theoretical and methodological approach]. Visnyk Zhytomyrs'koho natsional'noho ahroekolohichnoho universytetu, 1 (28), 41-42 (in Ukr.).

Одержано13.03.2018 p. 